\title{
Ältere Väter, mehr Mutationen beim Kind
}

\author{
Alte Väter haben Kinder mit stärker verändertem Erbgut. \\ Mit jedem zusätzlichen Lebensjahr des Vaters bei der Zeu- \\ gung steigt die Zahl der veränderten Stellen im Erbgut \\ des Kindes um zwei. Bereits ein 20-jähriger Vater über- \\ trägt im Durchschnitt rund 25 neue Mutationen an sein \\ Kind, ein 40-jähriger Vater etwa 65.
}

- Wissenschaftler aus Reykjavik (Island) verglichen die DNA von 78 isländischen Elternpaaren mit der ihrer Kinder. Im Fokus standen sogenannte De-novo-Mutationen. Dabei handelt es sich um genetische Veränderungen, die in den Keimzellen entstehen und sich erst bei den Kindern manifestieren. Mit der Anzahl der De-novo-Mutationen erhöht sich auch das Risiko des Kindes, z. B. an Autismus oder Schizophrenie zu erkranken.

Im Durchschnitt treten bei Kindern im Vergleich zu ihren Eltern etwa 60 De-novo-Mutationen auf Allerdings hängt die genaue Zahl stark vom Alter des Vaters zum Zeitpunkt der Zeugung ab: Kinder von 20-jährigen Vätern weisen etwa 25

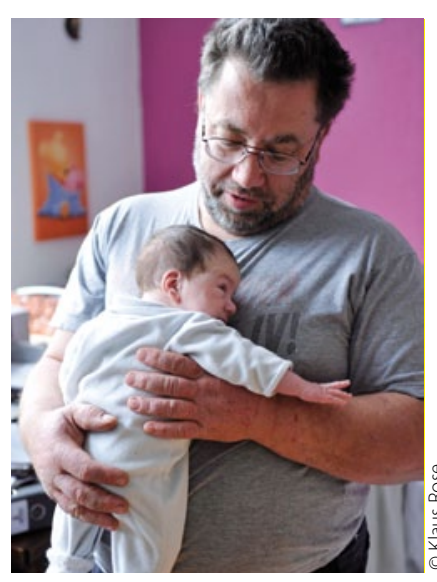

Zahl der De-novo-Mutationen hängt vom Alter des Vaters ab. neue Genveränderungen auf, der Nachwuchs von 40-Jährigen kommt auf durchschnittlich 65. Der starke lineare Effekt von gut zwei zusätzlichen Mutationen pro Jahr ist eindrucksvoll, so die Forscher.

\section{Kommentar}

Mütter tragen nur 15 neue $\mathrm{Mu}$ tationen zum Nachwuchs beiund das unabhängig von ihrem Alter. Eine Erklärung sehen die Forscher in der unterschiedlichen Art, wie männliche und weibliche Keimzellen entstehen. Bei Mädchen entstehen die Eizellen zu Beginn des Lebens und teilen sich anschließend nicht mehr. Ein Mann aber produziert Zeit seines Lebens kontinuierlich neue Spermien. Deren Vorläuferzellen durchlaufen also sehr viel mehr Teilungszyklen und sammeln somit auch mehr Mutationen an. Interessant sind die Ergebnisse nach Meinung der Wissenschaftler vor allem, weil die Menschen immer später Eltern werden. So waren Männer, die im Jahr 1980 Väter wurden, durchschnittlich 27,9 Jahre alt. 2011 Jahr lag das Durchschnittsalter bei 30 Jahren. Die 1980 geborenen Kinder hatten jeweils rund knapp 60, die 2011 geborenen fast 70 De-novo-Mutationen. 